Annals of Warsaw University of Life Sciences - SGGW

Land Reclamation No 38, 2007: 11-18

(Ann. Warsaw Univ. of Life Sci. - SGGW, Land Reclam. 38, 2007)

\title{
Phosphorus sorption capacity of different types of opoka
}

\author{
VICTOR CUCARELLA ${ }^{1}$, TOMASZ ZALESKI ${ }^{2}$, RYSZARD MAZUREK ${ }^{2}$ \\ ${ }^{1}$ Department of Land and Water Resources Engineering, Royal Institute of Technology (KTH), \\ Stockholm, Sweden \\ ${ }^{2}$ Department of Soil Science and Soil Protection, Agricultural University of Cracow, Poland
}

\begin{abstract}
Phosphorus sorption capacity of different types of opoka. The bedrock opoka has been lately reported as an appropriate reactive media for onsite wastewater treatment systems due to its high phosphorus $(\mathrm{P})$ sorption capacity. However, variations on its chemical composition may affect its reactivity with $\mathrm{P}$, therefore leading to a variable $P$ removal efficiency. In this paper, the P-sorption capacity of three different types of opoka from the region of Miechów, Poland, is reported. According to the silica and carbonate content, opoka samples were classified as light-weight and heavy-weight opoka. When heated over $900^{\circ} \mathrm{C}$, opoka showed a very high P-sorption capacity that was well correlated to its Ca content. P-sorption isotherms from batch experiments with an artificial $\mathrm{P}$ solution were plotted and fitted to the Langmuir and Freundlich adsorption models. The Freundlich isotherm appeared to model better the P-sorption of light opoka and the Langmuir isotherm of heavy opoka, suggesting different dominating mechanisms of P-sorption by light and heavy opoka.
\end{abstract}

Key words: calcium; freundlich isotherm; langmuir isotherm; opoka; phosphorus removal; silica; sorption.

\section{INTRODUCTION}

Reactive media with high phosphorus (P) sorption capacity are required in wetland and infiltration systems with the purpose of $\mathrm{P}$ removal from wastewater (Mann and Bavor, 1993; Zhu et al., 1997; Drizo et al., 1999). There has been extensive research on materials with noticeable
P sorption capacity (Sakadevan and Bavor, 1998; Angel, 1999; Johansson, 1999; Johansson Westholm, 2006). Natural calcareous soils and limestone are also known for its $\mathrm{P}$ retention ability (Zhou and Li, 2001). The $\mathrm{P}$ sorption capacity of a soil is closely related to the content of $\mathrm{Al}, \mathrm{Fe}$ and $\mathrm{Ca}$ as well as soil pH (Sakadevan and Bavor, 1998; Zhu et al., 1997). The bedrock opoka is a $\mathrm{Ca}$ rich sedimentary deposit with moderate to high $\mathrm{P}$-sorption capacity. It mainly consists of $\mathrm{SiO}_{2}$ and $\mathrm{CaCO}_{3}$ but also contains significant amounts of $\mathrm{Al}_{2} \mathrm{O}_{3}$ and $\mathrm{Fe}_{2} \mathrm{O}_{3}$ (Brogowski and Renman, 2004). Depending on the silica and carbonate content there is a large variability of opoka deposits ranging from 37.5 to $52.1 \%$ of silica and 34.5 $-50.4 \%$ of carbonate. Thus, opoka can be classified as light-weight (more $\left.\mathrm{SiO}_{2}\right)$ and heavy-weight opoka (more $\mathrm{CaCO}_{3}$ ) (Brogowski and Renman, 2004). Polish literature gives a wider range of silica content from 17.06 to $51.88 \%$ (Bolewski and Turnau-Morawska, 1963). This type of rock can also be classified as geza when the silica dominates.

It is known the ability of opoka to remove $\mathrm{P}$. The process occurs mainly through Ca-P interactions (Johansson and Gustafsson, 2000). Therefore, variations on its Ca content may account 
for differences in P-sorption. The P-sorption efficiency increases significantly when heated over $900^{\circ} \mathrm{C}$ due to the transformation of $\mathrm{CaCO}_{3}$ into $\mathrm{CaO}$, with an estimated sorption capacity of $119 \mathrm{~g} \mathrm{P} \mathrm{kg}^{-1}$ material (Brogowski and Renman, 2004).

The objective of this study was (i) to characterize opoka from three different quarries in the region of Miechów, Poland, and (ii) to evaluate its efficiency for $\mathrm{P}$ removal from wastewater. The short-term P-sorption was studied in batch experiments and the maximum sorption capacity was estimated through the Langmuir isotherm approximation.

\section{MATERIALS AND METHODS}

Opoka was acquired from three different quarries in the region of Miechów, Poland, located $60 \mathrm{~km}$ north of Cracow (Tab. 1). The samples were taken at a depth between 2-4 meters. The material was dried in the air and then in the oven at $105^{\circ} \mathrm{C}$.

The material was crushed and sieved to different fractions. Triplicate $2 \mathrm{~g}$ samples of the powdered fraction of natural opoka (Opk) and opoka heated to $900^{\circ} \mathrm{C}$ for 1 hour $(900 \mathrm{Opk})$, were used for analyse. Extraction with nitric and perchloric acids by heating for 3-4 days and later filtration, prepared the samples for atomic absorption and emission spectrometry. AAS Solar M6 and ICP-AES JY 238 Ultrace were used. The silica content was calculated from the weight of the filter remain after burning it at a temperature of $900{ }^{\circ} \mathrm{C}$. The $\mathrm{CaCO}_{3}$ content was analysed using the Scheibler's method. The $\mathrm{pH}$ was measured in a $1 \mathrm{M} \mathrm{KCl}$ solution in a proportion 1:2.5.

Triplicate $0.1 \mathrm{~g}$ samples of the powdered opoka heated to $900^{\circ} \mathrm{C}$ (900Opk) were placed in $50 \mathrm{ml}$ flasks with artificial P-solutions $\left(\mathrm{KH}_{2} \mathrm{PO}_{4}\right)$ of different $\mathrm{P}$ concentrations $(0,10$, 20, 50, 100, 200, 300, $500 \mathrm{mg} \mathrm{P} \cdot \mathrm{dm}^{-3}$ ) and then mixed in a rotator at $60 \mathrm{rpm}$ for 1 hour at room temperature $\left(21^{\circ} \mathrm{C}\right)$. After that time, the $\mathrm{pH}$ was measured and next, the samples were centrifuged at $6000 \mathrm{rpm}$ and then filtered through a $0.45 \mu \mathrm{m}$ membrane filter for $\mathrm{P}$ determination. The $\mathrm{P}$ was analysed using the standard ammonium molybdate method (Murphy and Riley, 1962) in a Beckman DU 600 spectrophotometer. The difference between the initial and final $P$ concentration at equilibrium was supposed to be sorbed to the material.

Sorption parameters were calculated using the Langmuir and Freundlich isotherms by plotting graphically the inverse and logarithm, respectively, of the sorbed portion (qs) against the inverse and logarithm of the solute concentration (Cs) at equilibrium, giving a straight line. The Langmuir and Freundlich constants are obtained from the intercept " $y$ " axis and the slope.

TABLE 1. Source of opoka in the region of Miechów

\begin{tabular}{|c|c|c|c|}
\hline Sample & Quarry & Bearings & Altitude \\
\hline Opk1 & Strzeżów & N 50 $23^{\prime} 04,8^{\prime \prime}$ EO $20^{\circ} 03^{\prime} 11,6^{\prime \prime}$ & $355 \mathrm{~m}$ \\
\hline Opk2 & Cisie (Antolka) & $\mathrm{N} 50^{\circ} 24^{\prime} 23,4^{\prime \prime}$ EO $20^{\circ} 05^{\prime} 36,7^{\prime \prime}$ & $348 \mathrm{~m}$ \\
\hline Opk3 & Widnica & 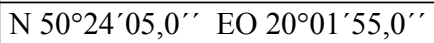 & $354 \mathrm{~m}$ \\
\hline
\end{tabular}


Langmuir: $\mathrm{qs}=\mathrm{k}_{\mathrm{L}} \cdot \mathrm{Cs} / 1+\mathrm{a}_{\mathrm{L}} \cdot \mathrm{Cs} \rightarrow$ $\rightarrow 1 / \mathrm{qs}=1 / \mathrm{Cs} \cdot 1 / \mathrm{k}_{\mathrm{L}}+\mathrm{a}_{\mathrm{L}} / \mathrm{k}_{\mathrm{L}}$

where $\mathrm{k}_{\mathrm{L}}\left(\mathrm{dm}^{3} \cdot \mathrm{g}^{-1}\right)$ reflects the adsorptivity and $a_{L}\left(\mathrm{dm}^{3} \cdot \mathrm{mg}^{-1}\right)$ is related to the energy of adsorption. $\mathrm{k}_{\mathrm{L}} / \mathrm{a}_{\mathrm{L}}\left(\mathrm{mg} \cdot \mathrm{g}^{-1}\right)$ is obtained from the intercept "y" axis and reflects the maximum adsorption capacity.

Freundlich: $\mathrm{qs}=\mathrm{a}_{\mathrm{F}} \cdot \mathrm{Cs}^{\mathrm{bF}} \rightarrow$

$\rightarrow \log \mathrm{qs}=\mathrm{b}_{\mathrm{F}} \cdot \log \mathrm{Cs}+\log \mathrm{a}_{\mathrm{F}}$

where $a_{F}\left(\mathrm{dm}^{3} \cdot \mathrm{g}^{-1}\right)$ expresses the adsorbent capacity (the larger value the higher the capacity) and $b_{F}$, which ranges from 0 to 1 , is the heterogeneity factor.

\section{RESULTS AND DISCUSSION}

\section{Chemical composition}

Table 2 shows the chemical composition of all three types of opoka in its natural and heated form. According to the silica and carbonate content, opoka can be classified as light-weight opoka (more $\mathrm{SiO}_{2}$ ) and heavy-weight opoka (more $\mathrm{CaCO}_{3}$ ). Figure 1 shows the deposits of opoka in the quarry of Strzeżów. Opoka from Strzeżów (Opk1) could be then classified as light opoka and the other two types, Opk2 from Cisie (Antolka) and Opk3 from Widnica, with higher carbonate content, could be catalogued as heavy opoka. There is a noticeable higher content of $\mathrm{Al}$ and $\mathrm{Fe}$ oxides in light opoka (Opk1). The rest of the components appear in similar proportions for all three types of opoka.

Light opoka has a high porosity whereas heavy opoka has a more compact structure due to its higher content of $\mathrm{CaCO}_{3}$ (Brogowski and Renman, 2004).
This could favour P movement through cavities and make more sorption places available. However, heavy opoka has a considerably higher content of $\mathrm{Ca}$ and a larger sorption capacity is expected.

Most of the $\mathrm{CaCO}_{3}$ and other possible $\mathrm{Ca}$ forms in opoka convert to $\mathrm{CaO}$ after heating to $900^{\circ} \mathrm{C}$. This has been already reported and it is the base of a strong Ca-P interaction due to the higher reactivity of $\mathrm{CaO}$ (Johansson and Gustafsson, 2000; Brogowski and Renman, 2004). The $\mathrm{pH}$ values increase drastically after heating, which also favours the $\mathrm{Ca}-\mathrm{P}$ reaction.

It has been observed a significant reduction in the $\mathrm{Al}$ and $\mathrm{Fe}$ content after heating of light opoka (Opk1) while it did not change much for Opk2 and Opk3. There is no noticeable change in the content of the other elements after heating to $900^{\circ} \mathrm{C}$ with the exception of a slight reduction of $\mathrm{Cu}$ for all three types of opoka.

\section{P-sorption capacity}

The batch experiments showed a high P-sorption capacity for powder fractions of all three materials heated to $900^{\circ} \mathrm{C}$. The natural form of opoka was not tested in this study since it has already been reported a low P-sorption capacity by Johansson, 1999. Light opoka (900Opk1) removed

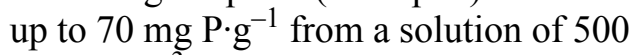
$\mathrm{mg} \mathrm{P} \cdot \mathrm{dm}^{-3}$ and its maximum sorption capacity was estimated in $79 \mathrm{mg} \mathrm{P} \cdot \mathrm{g}^{-1}$ by the Langmuir adsorption isotherm (Tab. 3). However, the experimental data fitted better to the Freundlich isotherm as shown in Figure 2.

The heavy opoka, both 900Opk2 and $9000 p k 3$, showed a higher sorption capacity than light opoka, removing 100 $\mathrm{mg} \mathrm{P} \cdot \mathrm{g}^{-1}$ and $120 \mathrm{mg} \mathrm{P} \cdot \mathrm{g}^{-1}$ respectively 
TABLE 2. Chemical composition of opoka samples (Opk: natural; 900Opk: heated)

\begin{tabular}{|l|rrr|r|r|r|}
\hline Element & Opk1 & Opk2 & Opk3 & 900 Opk1 & 900 Opk2 & 900 Opk3 \\
\hline $\mathrm{g} \mathrm{kg}^{-1}$ & & & & & & \\
$\mathrm{Si}$ & 231.32 & 169.34 & 154.57 & 310.67 & 248.37 & 210.05 \\
$\mathrm{Ca}$ & 171.34 & 296.55 & 311.58 & 220.79 & 364.39 & 419.75 \\
$\mathrm{Mg}$ & 2.56 & 2.77 & 2.83 & 2.02 & 2.78 & 3.11 \\
$\mathrm{Al}$ & 8.96 & 6.45 & 7.32 & 6.41 & 5.87 & 7.11 \\
$\mathrm{Fe}$ & 10.07 & 7.30 & 6.87 & 6.72 & 6.20 & 5.76 \\
$\mathrm{~K}$ & 0.42 & 0.29 & 0.34 & 0.39 & 0.32 & 0.32 \\
$\mathrm{Na}$ & 1.32 & 0.94 & 0.99 & 0.49 & 0.44 & 0.46 \\
$\mathrm{P}$ & 0.19 & 0.22 & 0.22 & 0.13 & 0.18 & 0.21 \\
\hline $\mathrm{mg} \mathrm{kg}{ }^{-1}$ & & & & & & \\
$\mathrm{Mn}$ & 41.43 & 50.15 & 42.33 & 36.87 & 75.18 & 43.41 \\
$\mathrm{Zn}$ & 19.87 & 20.99 & 19.58 & 15.19 & 18.31 & 15.74 \\
$\mathrm{Cu}$ & 5.31 & 5.37 & 6.16 & 2.32 & 2.56 & 3.41 \\
$\mathrm{Co}$ & 1.29 & 1.05 & 1.11 & 1.43 & 1.77 & 0.91 \\
$\mathrm{Cd}$ & $<0.5$ & $<0.5$ & $<0.5$ & $<0.5$ & $<0.5$ & $<0.5$ \\
\hline $\mathrm{pH}(\mathrm{KCl})$ & 7.48 & 7.65 & 7.55 & 12.40 & 12.41 & 12.41 \\
\hline
\end{tabular}

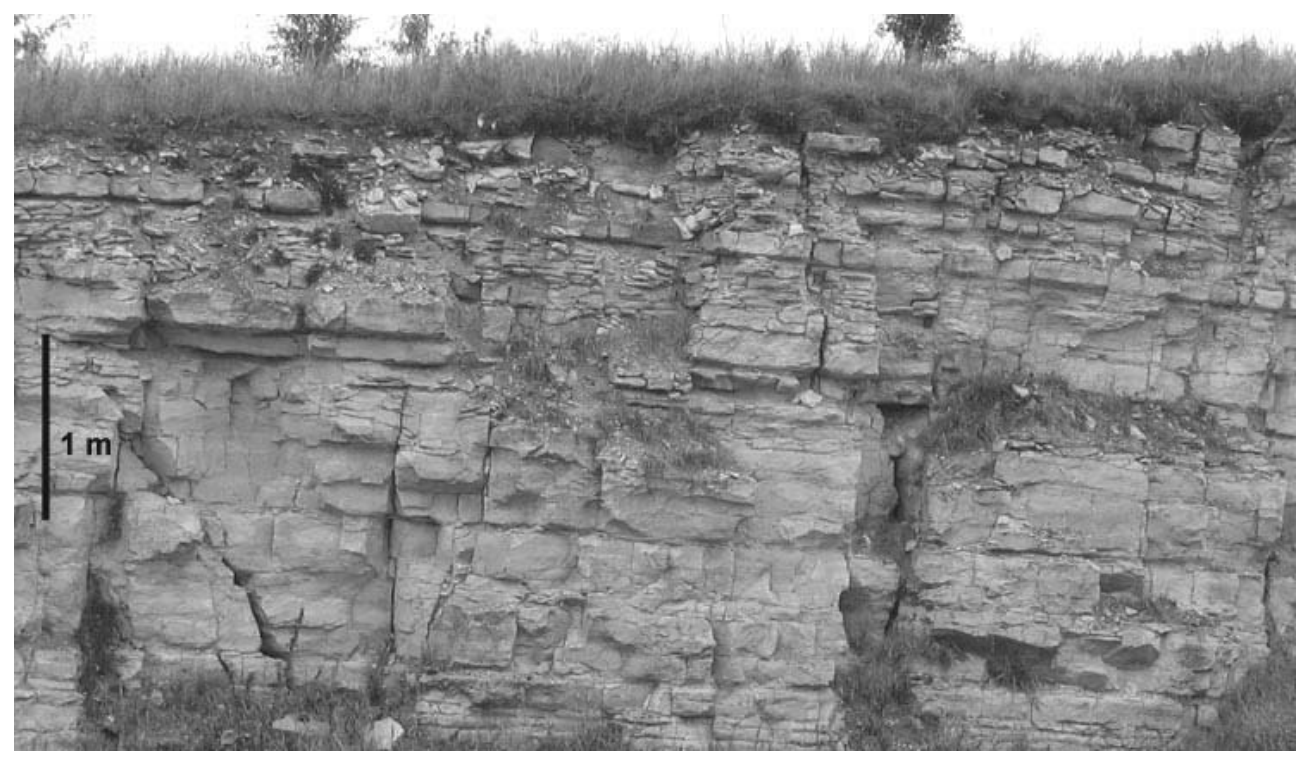

FIGURE 1. Quarry at Strzeżów (Miechów) 

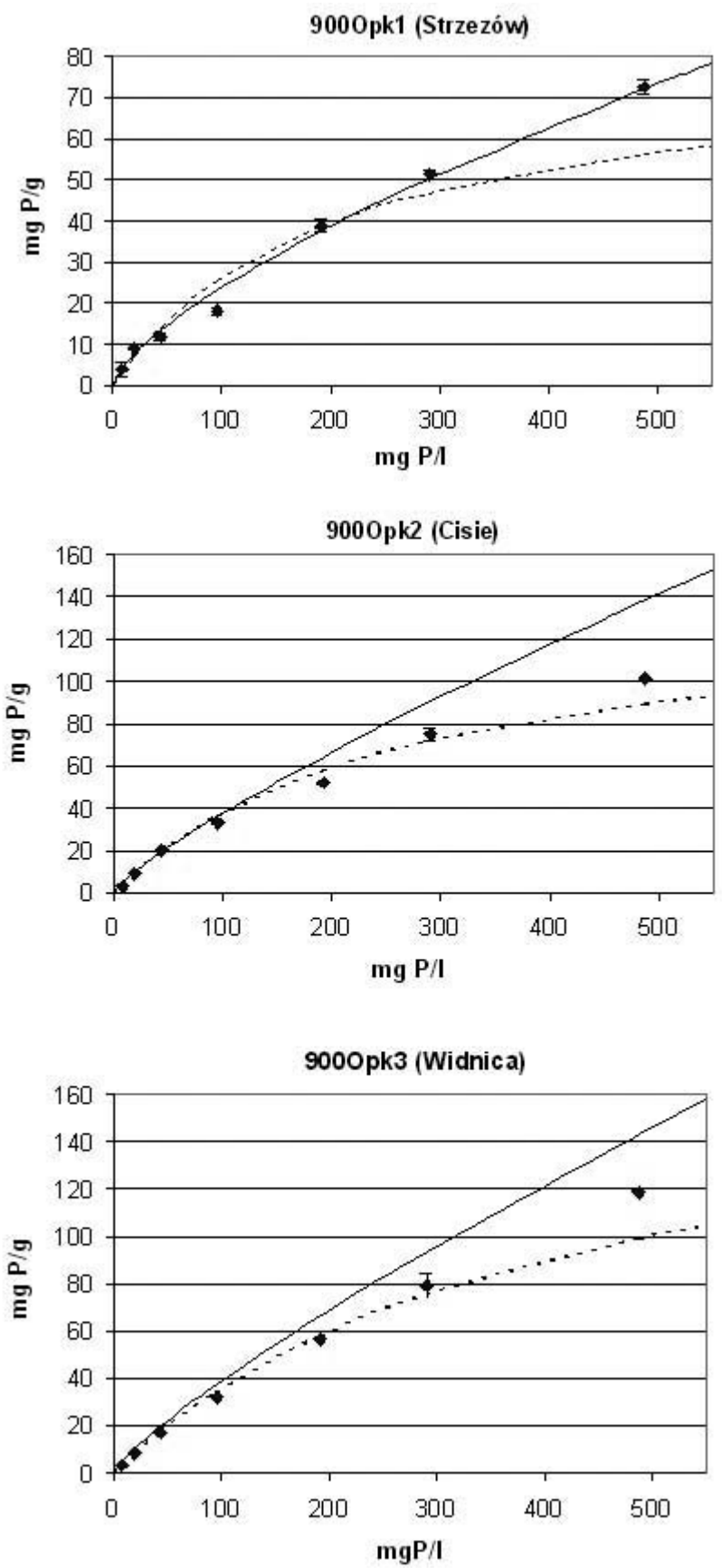

- Observed -...-. Langmuir —_Freundlich

FIGURE 2. Sorption isotherms of heated opoka with artificial P solutions 
from a solution containing $500 \mathrm{mg}$ $\mathrm{P} \cdot \mathrm{dm}^{-3}$ (Fig. 2). The experimental data for heavy opoka fitted better to the Langmuir isotherm and its estimated maximum adsorption capacity is given in Table 3. opoka while precipitation may contribute considerably to the $\mathrm{P}$-sorption process in heavy opoka.

There has been observed a very good correlation between the total

TABLE 3. P-sorption parameters from the Langmuir and Freundlich isotherms

\begin{tabular}{|l|c|c|c|c|c|c|}
\hline & \multicolumn{3}{|c|}{ Langmuir } & \multicolumn{3}{c|}{ Freundlich } \\
\hline Sample & $\mathrm{R}^{2}$ & $\mathrm{~kL}\left(\mathrm{dm}^{3} \cdot \mathrm{g}^{-1}\right)$ & $\mathrm{kL} / \mathrm{aL}\left(\mathrm{mg} \cdot \mathrm{g}^{-1}\right)$ & $\mathrm{R}^{2}$ & $\mathrm{aF}\left(\mathrm{dm}^{3} \cdot \mathrm{g}^{-1}\right)$ & $\mathrm{bF}$ \\
\hline 900Opk1 & 0.9777 & 0.3909 & 79.37 & 0.9836 & 0.9768 & 0.6950 \\
\hline 900Opk2 & 0.9973 & 0.5126 & 136.99 & 0.9833 & 0.8714 & 0.8192 \\
\hline 900Opk3 & 0.9991 & 0.4405 & 181.82 & 0.9994 & 0.8794 & 0.8227 \\
\hline
\end{tabular}

The results are comparable to those obtained by Brogowski and Renman who reported a sorption capacity of $119 \mathrm{mg} \mathrm{P \cdot g}$ 1 using a processed opoka from different origin (Brogowski and Renman, 2004).

The Freundlich equation, although empirical, implies that the affinity for adsorption decreases exponentially with increasing saturation, which may be closer to reality than the assumption of constant binding energy inherent in the Langmuir equation.

The Freundlich equation appear to model the equilibrium $\mathrm{P}$-adsorption data better than the Langmuir equation for many other reactive media studied before such as slags, zeolites, calcareous soils and limestone (Sakadevan and Bavor, 1998; Zhou and Li, 2001). The Freundlich $\mathrm{a}_{\mathrm{F}}$ values give a measure of the relative $\mathrm{P}$-adsorption capacity. However, these values are not directly related to the adsorption maxima from the Langmuir equation in the studied system. This has been previously observed by Sakadevan and Bavor, 1998, when using other reactive substrata and it was attributed to the precipitation of $\mathrm{P}$ in addition to $\mathrm{P}$ adsorption. Thus, adsorption mechanisms dominate in light
$\mathrm{Ca}$ content in heated opoka and its estimated (Langmuir) and observed (at $500 \mathrm{mg} \mathrm{P} \cdot \mathrm{dm}^{-3}$ ) maximum $\mathrm{P}$ adsorption capacity, with correlation coefficients of $\mathrm{R}=0.99$ and $\mathrm{R}=0.98$ respectively. This gives consistency to explain that Ca-P interaction drives the P-sorption mechanism in powdered opoka heated to $900^{\circ} \mathrm{C}$ and the more $\mathrm{CaO}$ the higher the sorption capacity.

Light opoka (Opk1) removed about $95 \%$ of P from a $10 \mathrm{mg} \mathrm{P} \cdot \mathrm{dm}^{-3}$ solution while heavy opoka (Opk2 and Opk3) removed $100 \%$. The removal efficiency of Opk 1 dropped to nearly $50 \%$ with a $50 \mathrm{mg} \mathrm{P} \cdot \mathrm{dm}^{-3}$ solution while it was necessary $200 \mathrm{mg} \mathrm{P} / 1$ or more to drop the efficiency of heavy opoka (Opk2 and Opk3) to $50 \%$. The $\mathrm{pH}$ values decreased with increasing $\mathrm{P}$ concentration from 11 to about 7. The P-sorption process in opoka is highly dependent on $\mathrm{pH}$ but this has not been the focus of this study.

These results are not applicable when using other fractions of opoka and they should be taken carefully. Courser fractions have higher hydraulic conductivity and therefore are more suitable for infiltration systems, however, they have lower porosity and its expected 
sorption capacity will be lower than that reported in this paper. The results of a column experiment using heated opoka with courser particle size $(2-5.5 \mathrm{~mm})$ showed a much lower P-sorbed load (Hylander et al., 2006). Furthermore, differences between light and heavy opoka regarding porosity (Brogowski and Renman, 2004) may cause the system to work properly or fail. Heavy opoka has a lower porosity and more compacted structure what leads often to clogging the system.

It is important to remember that this research has been performed with artificial $\mathrm{P}$ solutions and the results may differ when using wastewater due to the presence of other substances that could interfere the $\mathrm{P}$ interaction.

It is not known exactly what Ca-P compounds are formed in opoka, Depending on the $\mathrm{Ca}: \mathrm{P}$ ratio, pure $\mathrm{CaCO}_{3}$ can form four main different species (House, 1998). At low P concentrations, the main form is hydroxiapatite. P sorbed may be more or less available depending on the strength of the interaction and type of compound formed. It is known that hydroxiapatite is a strong component, in which form $\mathrm{P}$ is not available to plants (Johansson and Gustafsson, 2000). Further research shall test the plant availability of $\mathrm{P}$ sorbed to different types of opoka.

\section{CONCLUSIONS}

Opoka deposits in the region of Miechów, Poland, appear to vary considerably. Depending on its chemical composition, the rock was grouped as light-weight opoka (Strzeżów), with predominant silica, and heavy-weight opoka (Cisie and Widnica), with higher carbonate content. There is a noticeable higher content of
$\mathrm{Al}$ and $\mathrm{Fe}$ oxides in light opoka. The P-sorption capacity increases considerably when heating the material up to $900^{\circ} \mathrm{C}$ and in that form, its $\mathrm{P}$ -sorption capacity is directly related to the $\mathrm{CaO}$ content. P-sorption maximum capacities of about 70 and $100-120 \mathrm{mg}$ $\mathrm{P} \mathrm{g}^{-1}$ have been observed for powdered light and heavy opoka respectively. The Langmuir isotherm estimates in 80 $\mathrm{mg} \mathrm{P} \cdot \mathrm{g}^{-1}$ and $137-181 \mathrm{mg} \mathrm{P}^{-1}$ the P-sorptioncapacities ofthetestedpowdered light and heavy opoka respectively. The P-sorption isotherms fitted well to the Freundlich adsorption model for light opoka and to the Langmuir isotherm for heavy opoka, showing that different mechanisms govern the P-sorption process in light and heavy opoka. Further research shall focus on the study of the plant available $\mathrm{P}$ of different types of opoka.

\section{ACKNOWLEDGMENTS}

Research funding was received from the European Commission through a Marie Curie Training Site at the Foundation for Materials Science Development, Cracow, headed by Prof. Ryszard Ciach. The work was performed at the Agricultural University of Cracow. I would like to thank Assoc. Prof. Gunno Renman at the department of Land and Water Resources Engineering, KTH, and Prof. Brogowski at Warsaw University of Life Sciences for advice and comments on the manuscript.

\section{REFERENCES}

ANGEL R. 1999: Removal of phosphate from sewage as amorphous calcium phosphate. Environ. Technol. 20 (7): 709-720. 
BOLEWSKI A.,TURNAU-MORAWSKA M. 1963: Petrografia. Wydawnictwa Geologiczne. Warszawa.

BROGOWSKI Z., RENMAN G. 2004: Characterisation of Opoka as a Basis for its use in wastewater treatment. Polish J. of Environ. Studies 13 (1): 15-20.

DRIZO A., FROST C., GRACE J., SMITH K. 1999: Physico-chemical screening of phosphate-removing substrates for use in constructed wetland systems. Water Res. 33 (17): 3595-3602.

GRIFFIN R.A., JURINAK J. J. 1974: Kinetics of the phosphate interaction with calcite. Soil Sci. Soc. Amer. Proc., vol 38.

HYLANDER L., KIETLINSKAA., RENMAN G., SIMÁN G. 2006: Phosphorus retention in filter materials for wastewater treatment and its subsequent suistability for plant production. Biores. Technol. 97: 914-921.

HOUSE W.A. 1999: The physico-chemical conditions for the precipitation of phosphate with calcium. Int. conf. on phosphorus recovery, Warwik University, UK.

JOHANSSON L. 1998: Industrial by-products and natural substrata as phosphorus sorbents. Environ. Technol. 20: 309-316.

JOHANSSON L., GUSTAFSSON J.P. 2000: Phosphate removal from wastewaters using blast furnace slags and opoka Mechanisms. Water Res. 34 (1): 259-265.

JOHANSSON WESTHOLM L. 2006: Substrates for phosphorus removalPotential benefits for on-site wastewater treatment. Water Res. 40: 23-36.

MANN R.A., BAVOR H.J. 1993: Phosphorus removal in constructed wetlands using gravel and industrial waste substrata. Wat. Sci. Tech. 27 (1): 107-113.

MURPHY J., RILEY J.P. 1962: A modified single solution method for the determination of phosphate in natural waters. Anal. Chim. Acta 27: 31-36.

SAKADEVAN K., BAVOR H. 1998: Phosphate adsorption characteristics of soils, slags and zeolites to be used as substrates in constructed wetland systems. Water Res., 22 (2): 393-399.
ZHOU M., LI Y. 2001: Phosphorus-sorption characteristics of calcareous soils and limestone from the southern Everglades and adjacent farmlands. Soil. Sci. Soc. Am. J. 65: 1404-1412.

ZHU T., JENSSEN P.D., MAEHLUM T., KROGSTAD T. 1997: Phosphorus sorption and chemical characteristics of lightweight aggregates (LWA) - potential filter media in treatment wetlands. Wat. Sci. Tech. 35 (5): 103-108.

Streszczenie: Zdolność wchtaniania fosforu przez różne rodzaje opoki. Według ostatnich badań opoka jest uważana za sorbent, który ze względu na wysoka zdolność wiązania fosforu, może mieć zastosowanie $\mathrm{w}$ przydomowych oczyszczalniach ścieków. Jednakże różnorodność składu chemicznego opoki wpływa na intensywność wiązania $\mathrm{P}$ i prowadzi do różnej efektywności procesu oczyszczania ścieków. W pracy przedstawiono zdolność wiązania P przez trzy rodzaje opok pobranych w rejonie Miechowa (woj. małopolskie). Na podstawie zawartości krzemionki i węglanów próbki zostały podzielone na opokę lekką i ciężką. Po wypaleniu w temperaturze ponad $900^{\circ} \mathrm{C}$ opoka charakteryzowała się bardzo wysoką zdolnością wiązania $\mathrm{P}$, silnie skorelowaną z zawartością $\mathrm{Ca}$. Krzywe sorpcji $\mathrm{P}$, otrzymane podczas doświadczenia ze sztucznie sporządzonym roztworem zawierającym rozpuszczony $\mathrm{P}$, porównano $\mathrm{z}$ modelami absorpcji opracowanymi przez Langmuira i Freundlicha. Izoterma Freundlicha była bardziej zbliżona do krzywej wiązania P przez opokę lekką, z kolei model Langmuira okazał się bliższy krzywej sorpcji opoki ciężkiej.

\section{MS. received 10 December 2007}

\section{Authors' addresses:}

Victor Cucarella

Department of Land and Water Resources

Engineering; Brinellvägen 28

S-100 44 Stockholm, Sweden

Tel.: +468 790 6350; fax: +4684110775

e-mail address: victorcc@kth.se

Tomasz Zaleski, Ryszard Mazurek

Agricultural University of Cracow, Dept. of Soil Science and Soil Protection

Al. Mickiewicza 21, 31-120 Cracow, poland Tel.: +48 1266243 70; fax: +48 126624370 e-mail address: tzaleski@ar.krakow.pl, rrmazue@cyf-kr.edu.pl 